\title{
OXIDATIVE ALTERATION OF SPENT FUEL IN A SILICA-RICH ENVIRONMENT: SEM/AEM INVESTIGATION AND GEOCHEMICAL MODELING
}

Yifeng Wang ", Huifang Xu"*

"Sandia National Laboratories, 4100 National Parks Highway, Carlsbad, New Mexico 88220. E-mail: ywang@sandia.gov

"* Department of Earth and Planetary Sciences, The University of New Mexico, Albuquerque, New Mexico 87131. E-mail: hfxu@unm.edu

\begin{abstract}
Correctly identifying the possible alteration products and accurately predicting their occurrence in a repository-relevant environment are the key for source-term calculations in a repository performance assessment. Uraninite in uranium deposits has long been used as a natural analog to spent fuel in a repository because of their chemical and structural similarity. In this paper, a SEM/AEM investigation has been conducted on a partially alterated uraninite sample from a uranium ore deposit of Shinkolobwe of Congo. The mineral formation sequences were identified: uraninite $\rightarrow$ uranyl hydrates $\rightarrow$ uranyl silicates $\rightarrow$ Ca-uranyl silicates or uraninite $\rightarrow$ uranyl silicates $\rightarrow$ Ca-uranyl silicates. Reaction-path calculations were conducted for the oxidative dissolution of spent fuel in a representative Yucca Mountain groundwater. The predicted sequence is in general consistent with the SEM observations. The calculations also show that uranium carbonate minerals are unlikely to become major solubility-controlling mineral phases in a Yucca Mountain environment. Some discrepancies between model predictions and field observations are observed. Those discrepancies may result from poorly constrained thermodynamic data for uranyl silicate minerals.
\end{abstract}

\section{INTRODUCTION}

It is proposed in the United States that spent fuel will be disposed in a geologic repository at Yucca Mountain, Nevada. In such an oxidizing and silica-rich subsurface environment, spent fuel $\left(\mathrm{UO}_{2}\right)$ will experience complex alteration processes when it contacts with incoming groundwater. The alteration will include the oxidative dissolution of $\mathrm{UO}_{2}$ and the formation of various uranium-bearing secondary mineral phases, which usually act as a secondary waste form and directly control the mobility of uranium in a repository environment. Therefore, correctly identifying the possible alteration products and accurately predicting their occurrence in repository-relevant environments are the key for the source-term calculation in a repository performance assessment. Uraninite $\left(\mathrm{UO}_{2+x}\right)$ in uranium deposits has long been used as a natural analog to spent fuel in a repository because of their chemical and structural similarity $[1,2]$. In this paper, we present our scanning electron microscopy(SEM) and analytical electron microscopy (AEM) observations on uraninite alteration in a sample from a uranium ore deposit of Shinkolobwe of Congo. Based on the observations, we conduct thermodynamic 


\section{DISCLAIMER}

Portions of this document may be illegible in electronic image products. Images are produced from the best available original document. 


\section{DISCLAIMER}

This report was prepared as an account of work sponsored by an agency of the United States Government. Neither the United States Government nor any agency thereof, nor any of their employees, make any warranty, express or implied, or assumes any legal liability or responsibility for the accuracy, completeness, or usefulness of any information, apparatus, product, or process disclosed, or represents that its use would not infringe privately owned rights. Reference herein to any specific commercial product, process, or service by trade name, trademark, manufacturer, or otherwise does not necessarily constitute or imply its endorsement, recommendation, or favoring by the United States Government or any agency thereof. The views and opinions of authors expressed herein do not necessarily state or reflect those of the United States Government or any agency thereof. 
calculations to constrain the possible reaction paths of spent fuel alteration in a silica-rich environment. The capability and limitation of the current thermodynamic model are also discussed.

\section{SAMPLE AND EXPERIMENTAL METHOD}

A partially altered (weathered) uraninite is from a uranium ore deposit of Shinkolobwe of Congo. The surrounding rocks of the ore deposit are dolomitic siltstones. The oxidative alteration of uraninite was caused by downward meteoric water. Polished thin section was prepared for scanning electron microscopy (SEM) investigation. Crushed uraninite powder crystals were used for transmission electron microscopy (TEM) and electron energy-loss spectroscopy (EELS) analyses. Oxidation states of U were determined using a FEG TEM (Philips 420 ST) and associated Gatan PEEL system [3].

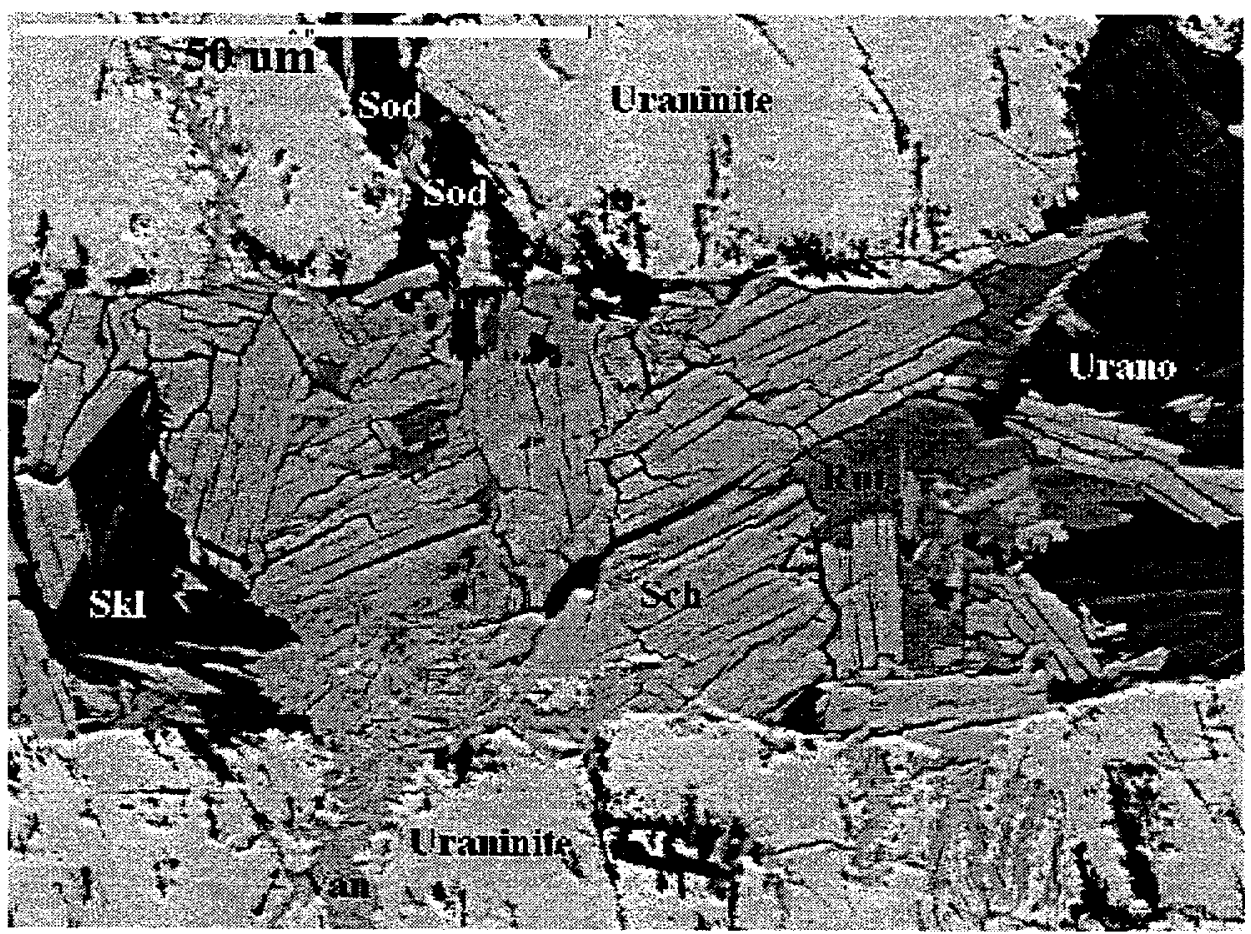

Figure 1. SEM image of a weathered uraninite $\left(\mathrm{UO}_{2.5}\right)$ sample from a uranium ore deposit of Shinkolobwe of Congo. Sod - soddyite $\left(\left(\mathrm{UO}_{2}\right)_{2} \mathrm{SiO}_{4} \cdot 2 \mathrm{H}_{2} \mathrm{O}\right)$, Urano uranophane $\left(\mathrm{Ca}\left(\mathrm{UO}_{2}\right)_{2} \mathrm{Si}_{2} \mathrm{O}_{7} \cdot 6 \mathrm{H}_{2} \mathrm{O}\right)$, Sch - Schoepite $\left(\mathrm{UO} 3 \cdot 2 \mathrm{H}_{2} \mathrm{O}\right), \mathrm{Skl}-$ sklodowskite $\left(\mathrm{Mg}\left(\mathrm{UO}_{2}\right)_{2} \mathrm{Si}_{2} \mathrm{O}_{6}(\mathrm{OH})_{2} \cdot 5 \mathrm{H}_{2} \mathrm{O}\right)$, Van - vandendriesscheite $\left(\mathrm{PbU}_{7} \mathrm{O}_{22} \cdot 12 \mathrm{H}_{2} \mathrm{O}\right)$, Rut - rutherfordine $\left(\mathrm{UO}_{2} \mathrm{CO}_{3}\right)$. 
SEM results indicate that the main alteration products are schoepite, soddyite and uranophane (Figure 1). Other U-bearing phases are sklodowskite, rutherfordine, and kasolite $\left(\mathrm{Pb}\left(\mathrm{UO}_{2}\right) \mathrm{SiO}_{4} \cdot \mathrm{H}_{2} \mathrm{O}\right)$. Silica-free $\mathrm{U}^{6+}$-bearing minerals (such as schoepite) are the reaction products of uraninite with silica-depleted solutions. Alteration reactions preferentially occur along fractures in a uraninite crystal. Electron energy-loss spectroscopy results show the $\mathrm{U}^{6+} \mathrm{U}^{4+}$ ratio of uraninite is about $1 / 1$. TEM results indicate that uraninite crystals are heterogeneous in crystallinity and composition (especially $\mathrm{Pb}$ concentration) (Figure 2). The alteration products of the uraninite, such as soddyite, are relatively poor in $\mathrm{Pb}$ with respect to the uraninite. Radiation damage caused by alpha decay mainly results in low crystallinity of uraninite (Figure 2 ).

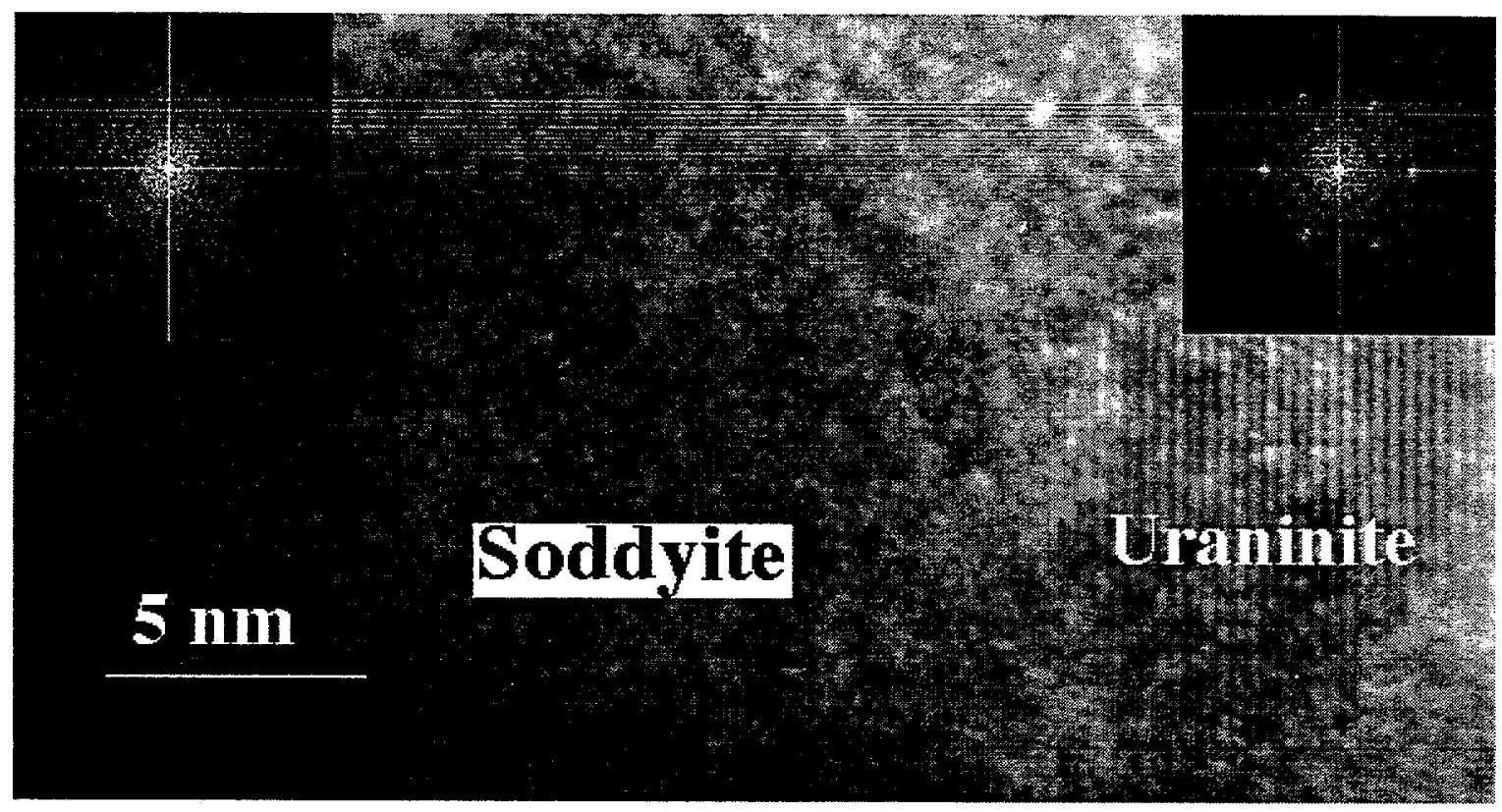

Figure 2. TEM image showing an interface between the uraninite and its alteration products, soddyite. EDS spectra indicate that the soddyite is relatively poor in $\mathrm{Pb}$ with respect to the uraninite. Inserted patterns on the upper corners are Fast Fourier Transform (FFT) of the image from soddyite and uraninite areas. Amorphous feature of the soddyite is caused by irradiation of high-energy electron beam (radiation damage).

The mineral formation sequence can be identified from the SEM image (Figure 1). Uraninite was directly replaced by either soddyite or schoepite. The soddyite was in turn replaced by uranophane. The early-formed schoepite could be replaced either by carbonate unranyl mineral phases such as rutherfordine or by uranyl silicates such as soddyite and uranophane. Lead, a fission product of uranium, was leached during uraninite alteration and was precipitated as vandendriesscheite next to uraninite grains. The occurrence of $\mathrm{Mg}$ uranyl silicate mineral (sklodowskite) and uranyl carbonate (rutherfordine) reflects the surrounding carbonate environment. 


\section{GEOCHEMICAL MODELING}

Computer code EQ3/6 $[4,5]$ with an enhanced thermodynamic data was used to calculate the reaction path of spent fuel alteration in an oxidizing, silica-rich repository environment. In order to make our calculations more relevant to the Yucca Mountain environments, we use the composition of water from well J-13 at the Nevada Test Site. This water is often used to represent the groundwater at the proposed high level waste repository at Yucca Mountain, Nevada [6]. Two sets of reaction-path calculations were conducted. In both of them, $\mathrm{UO}_{2}$ was titrated into one kilogram of J-13 groundwater with a fixed $\mathrm{O}_{2}$ fugacity of $3.3 \times 10^{-31}$ atm and $\mathrm{CO}_{2}$ fugacity of $5.0 \times 10^{-3} \mathrm{~atm}$, which were calculated from the initial groundwater composition. In the first set of calculation, we assume that the groundwater is not buffered by ambient rocks. This set of calculations mimics spent fuel dissolution in the near field, that is, close to waste packages. In contrast, in the second set of calculations, we assume that the groundwater is always buffered by a silicate mineral (microcline) and carbonate mineral (calcite). The calculation results are presented in Figures 3 and 4.

As shown in Figure 3A, in the near field of a disposal room, depending on the relative rate of spent fuel dissolution to silica supply by incoming groundwater, the solution next to a waste package can become depleted in silica, resulting in the formation of uranyl hydrates $\left(\mathrm{UO}_{3} .2 \mathrm{H}_{2} \mathrm{O}\right)$. Away from the waste package, the uranyl hydrates will then be replaced by soddyite and $\mathrm{CaUO}_{4}$, depending on the initial concentrations of $\mathrm{Si}$ and $\mathrm{Ca}$ in the incoming water. Farther away from the waste package, the soddyite will be replaced by Ca-uranyl silicate (e.g., haiweeite $\left(\mathrm{Ca}\left(\mathrm{UO}_{2}\right)_{2}\left(\mathrm{Si}_{2} \mathrm{O}_{5}\right)_{3} \cdot 5 \mathrm{H}_{2} \mathrm{O}\right)$ ). Figure 3B shows that the silica concentration in the groundwater have a great impact on uranium solubility. In an oxidizing environment, the solubility of uranium in a silica-depleted groundwater is generally at least two magnitude orders higher than that in a silica-rich solution. Note that in a silica-depleted environment the oxidative dissolution of spent fuel has little impact on solution $\mathrm{pH}$.

Farther away from a waste package, for instance, in the far field, the groundwater is most likely to be buffered by minerals in the host rock. Figure 4 displays the reaction path of spent fuel dissolution in the J13 groundwater buffered by both microcline and calcite. In this case, spent fuel will be directly replaced by soddyite, which will be in turn replaced by haiweeite. The formation of soddyite will induce silicate dissolution, resulting in an increase in solution $\mathrm{pH}$ and therefore the solubility of uranium in the solution. 


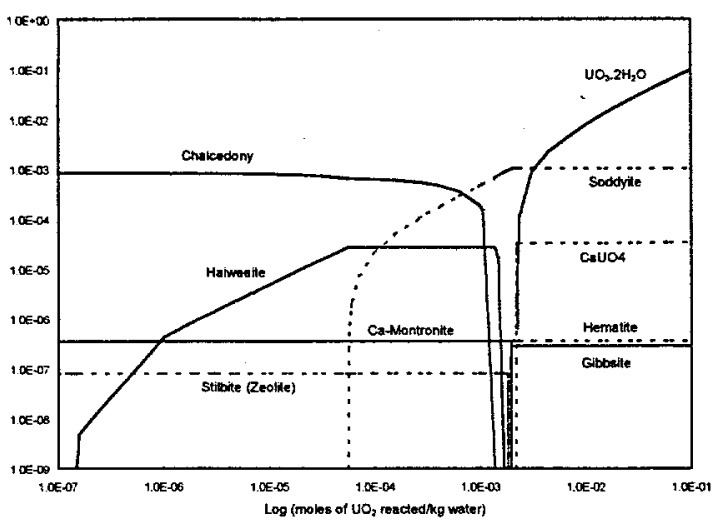

A

Figure 3. Reaction-path calculation of oxidative dissolution spent fuel in the J13 groundwater. In the calculation, the solution is not buffered by microcline and calcite.

Our computer simulations show that the predicted mineral formation sequence is quite stable for a given $\mathrm{O}_{2}$ and $\mathrm{CO}_{2}$ fugacity. The predicted sequence is in general consistent with our SEM observations on a natural analog sample. That is, in an oxidizing and silica-rich environment, the alteration of uraninite (or spent fuel) follows two reaction paths: uraninite $\rightarrow$ uranyl hydrates $\rightarrow$ uranyl silicates $\rightarrow$ Ca-uranyl silicates or uraninite $\rightarrow$ uranyl silicates $\rightarrow$ Ca-uranyl silicates. Our simulations also show that uranium carbonate minerals are unlikely to become major solubility-controlling mineral phases in Yucca Mountain environments. However, some discrepancies are observed between model prediction and field observations in detail mineral phases. For example, the SEM observation shows that a dominant $\mathrm{Ca}$-uranyl silicate mineral is uranophane instead of haiweeite as model predicted. In the calculation, uranophane can precipitate only when both soddyite and haiweeite are suppressed. This discrepancy may result from the poorly constrained thermodynamic data for uranophane in the computer database. 


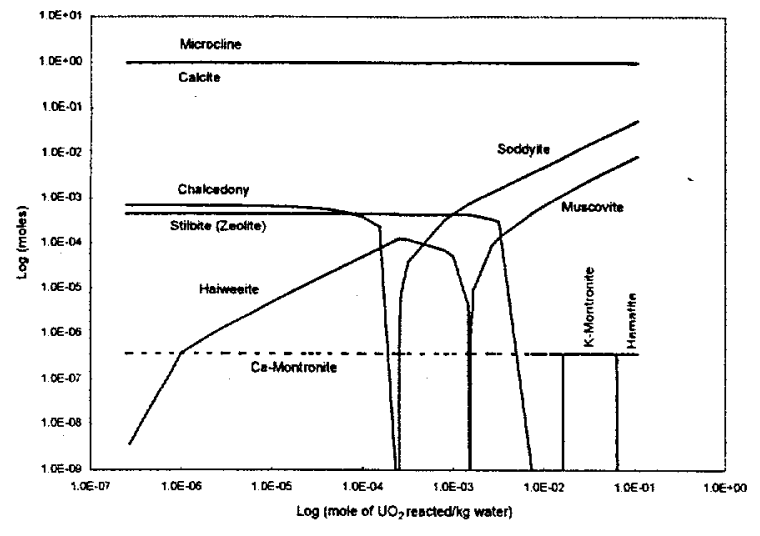

A

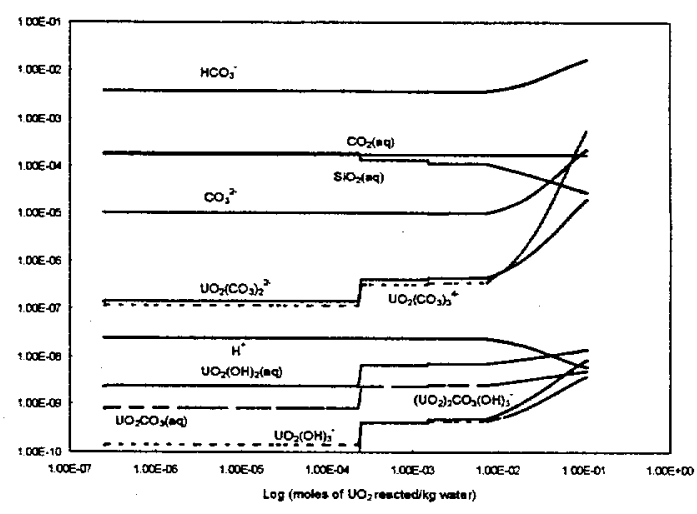

B

Figure 4. Reaction-path calculation of oxidative dissolution spent fuel in J13 groundwater. In the calculation, the solution is buffered by microcline and calcite.

\section{CONCLUSIONS}

A SEM/AEM investigation has been conducted on a partially alterated uraninite sample obtained from a uranium ore deposit of Shinkolobwe of Congo. The mineral formation sequences were identified: uraninite $\rightarrow$ uranyl hydrates $\rightarrow$ uranyl silicates $\rightarrow$ Ca-uranyl silicates or uraninite $\rightarrow$ uranyl silicates $\rightarrow$ Ca-uranyl silicates. Reaction-path calculations were conducted for the oxidative dissolution of spent fuel in a representative Yucca Mountain groundwater. The predicted sequence is in general consistent with the SEM observations. The calculations also show that uranium carbonate minerals are unlikely to become major solubility-controlling mineral phases in a Yucca Mountain environment. Some discrepancies exist between model predictions and field observations in terms of the occurrence of uranophane. This discrepancy may result from the poorly constrained thermodynamic data for some uranyl silicate minerals.

\section{ACKNOWLEDGMENTS}

Sandia is a multiple laboratory operated by Sandia Corporation, a Lockheed Martin Company, for the United States Department of Energy (US DOE) under Contract DE-AC04-94AL85000. This work is based upon a research conducted at the Transmission Electron Microscopy Laboratory in the Department of Earth and Planetary Sciences of the University of New Mexico, which is partially supported by NSF and State of New Mexico. H. Xu also acknowledge the NSF of China for partial support of the study. 


\section{REFERENCES}

1. R.J. Finch and R.C. Ewing, J. Nucl. Mater., 190, p. 133-156 (1992).

2. M. Fayek, T.K. Kyser, R.C. Ewing, and M.L. Miller, in Scientific Basis for Nuclear Waste Management XX, Boston (Dec. 2-6, 1996), edited by W.J. Gray and I.R. Triay (Mater. Res. Soc. Symp. Proc., 465, Pittsburgh, PA, 1997) pp. 1201-1207.

3. H. Xu and Y. Wang, J. Nucl. Mater., 265, p. 117-123 (1999).

4. T.J. Wolery, EQ3NR, A Computer Program for Geochemical Aqueous SpeciationSolubility Calculations: Theoretical Manual, User's Guide, and Related Documentation (Version 7.0), Lawrence Livermore National Laboratory, Livermore, CA, Report UCRL-MA-110662 Pt. III (1992).

5. T.J. Wolery and S.A. Daveler, EQ6, A Computer Program for Reaction Path Modeling of Aqueous Geochemical Systems: Theoretical Manual, User's Guide, and Related Documentation (Version 7.0), Lawrence Livermore National Laboratory, Livermore, CA, Report UCRL-MA-110662 Pt. IV (1992).

6. J.E. Harrar, J.F. Carley, W.F. Isherwood, and E. Raber, Report of Committee to Review the Use of J-13 Well Water in Nevada Nuclear waste Storage Investigations. Lawrence Livermore National Laboratory, Report UCID-21867 (1990) 